\section{Israel-Aina YT Omoigberale AI}

DOI:http://dx.doi.org/10.4314/njp.v39i4.2

Accepted: 13th March 2012

Israel-Aina YT ( $\square)$

Omoigberale AI

Department of Child Health,

University of Benin Teaching

Hospital,

Benin City, Edo State,

Nigeria

\title{
Risk factors for neonatal jaundice in babies presenting at the University of Benin Teaching Hospital, Benin City
}

\begin{abstract}
Background: Jaundice is the yellowish discoloration of the skin, sclera and mucous membranes resulting from deposition of bilirubin. Neonatal jaundice is a leading cause of neonatal admissions in the first week of life and risk factors such as sepsis, prematurity, glucose-6-phosphate dehydrogenase enzyme deficiencies, use of native herbs and contact with naphthalene balls contaminated clothes have been identified for neonatal jaundice.

Objective: To determine the risk factors for neonatal jaundice at University of Benin Teaching Hospital, Benin City.

Methods: This retrospective study was conducted at the Special Care Baby Unit of the University of Benin Teaching Hospital, Benin City. Case notes of babies admitted from January 2006 to December 2008 were retrieved and information on biodata, gestational age, anthropometric values, potential risk factors, level of serum bilirubin at presentation and discharge, mode of treatment and outcome were extracted.

Results: Of the 1784 babies admitted during the period, 472 (26.5\%)

ered in UBTH (in-born babies), while $202(42.8 \%)$ of the babies were born before arrival (out-born babies) in UBTH. The Male: Female ratio was 1.02:1. The mean age at presentation with jaundice was $3.43 \pm 3.76$ days of life. Outborn babies tended to present at an older age (6.08 \pm 5.19 days) than in -born babies $(2.47 \pm 2.48$ days). The mean serum bilirubin value in out-born babies $(14.00 \pm 4.58 \mathrm{mg} /$ dL) was significantly higher than that observed among the in-born babies $(9.35 \pm 4.38 \mathrm{mg} / \mathrm{dL}: \mathrm{p}=$ $0.000)$. The risk factors identified were use of mentholatum, naphthalene balls and native herbs in $40.0 \%, 16.7 \%$ and $7.0 \%$ respectively. ABO incompatibility was found in $7.6 \%$ of babies. No risk factor was identified in $36.3 \%$ of the babies. The case fatality rate in this study was relatively high particularly in association with sepsis, prematurity and asphyxia. Mortality was higher in out-born babies than in in-born babies $(\mathrm{p}=0.00)$.

Conclusion: Early presentation of babies and adequate management of sepsis and prematurity will reduce mortality associated with neonatal jaundice.
\end{abstract} were admitted for neonatal jaudice. Fifty seven percent of the babies with neonatal jaundice were deliv-
Key words: In-born, jaundice, outborn, risk, sepsis.

\section{Introduction}

Jaundice is the yellowish discoloration of the skin, sclera and mucous membranes resulting from deposition of bilirubin. ${ }^{1-2}$ Neonatal hyperbilirubinaemia is defined as serum bilirubin greater than $5 \mathrm{mg} / \mathrm{dL}$ and it occurs when the rate of bilirubin production exceeds excretion from the body. ${ }^{1-3}$ Bilirubin production in the newborn is two to three times higher per kilogram body weight than in adults. This is due to the high red cell mass and re- duced red blood cell lifespan while accumulation results from a relatively low rate of conjugation of bilirubin by the liver. The resultant effect of this is an increase in unconjugated, non polar lipid soluble bilirubin that is deposited in the skin. ${ }^{3-4}$ Excessive rise in the level of unconjugated bilirubin is of great clinical concern because this form of bilirubin is neurotoxic and can cause death in the newborn period as well as lifelong neurological sequellae. Conjugated bilirubin is not neurotoxic, but it may signify a serious disorder in the newborn. ${ }^{3-6}$ 
Neonatal jaundice is a very common clinical condition and over $60 \%$ of term newborns and $80 \%$ of preterm neonates will develop jaundice in the first week of life. ${ }^{1,5-7}$ Neonatal jaundice is a leading cause of neonatal admissions in the first week of life and constitutes an important cause of neonatal morbidity and mortality. ${ }^{5-7}$ In developed countries, risk factors include haemolytic diseases (Rhesus isoimmunisation and ABO haemolytic disease), prematurity, sepsis, and enzyme deficiencies (Uridyl diphosphate glucoronyl transferase enzyme deficiency). ${ }^{1-7}$ In Nigeria, neonatal sepsis, prematurity, glucose-6-phosphate dehydrogenase enzyme deficiency, use of native herbs and contact with naphthalene balls contaminated clothes have been identified as risk factors for neonatal jaundice..$^{7-11}$ The present study was undertaken to determine the prevalent risk factors for neonatal jaundice at University of Benin Teaching Hospital, Benin City.

\section{Subjects and methods}

The study population consisted of babies admitted into the special care baby unit (SCBU) of the University of Benin Teaching Hospital from January 2006 to December 2008. The special care baby unit of the hospital is a 50 -bed ward. It provides care to babies born in the hospital and others referred from elsewhere in Edo State and neighbouring States. Ethical approval was given by the Ethics Committee of the hospital. The babies' case notes were retrieved from the medical records of the hospital and information on biodata, demographic characteristics, gestational age, anthropometric measurements, potential risk factors, level of serum bilirubin at presentation and discharge, mode of treatment and outcome were extracted.

Analysis of data was done using the Statistical Package for Social Sciences (SPSS) version 16.0 (SPSS Inc. Chicago IL). Measures of statistical location like mean and standard deviation of continuous variables were computed and frequency tables generated as required. $P$ values less than 0.05 were considered significant.

\section{Results}

Of the 1784 babies admitted into SCBU from January 2006 to December 2008, 472 (26.5\%) were admitted for neonatal jaundice. Two hundred and seventy $(57.2 \%)$ of the babies with neonatal jaundice were delivered in UBTH (Inborn babies), while 202 (42.8\%) of the babies were born before arrival (out born babies) in UBTH.

Fifty seven percent (270/472) of the babies with neonatal jaundice were males while 202/472 (42.8\%) were females. The gender representation of the study population was comparable (Male: female ratio was 1.02:1, $\mathrm{p}=$ 0.67).

Two hundred and ninety $(61.4 \%)$ of the 472 mothers booked for antenatal care in pregnancy while 182/472 (38.6\%) did not. Mothers of the in-born subjects were more likely to book in pregnancy than mothers of the out-born subjects $\left(49 \%\right.$ Vs $13 \%, \chi^{2}=147.81, p=0.000$ : $95 \% \mathrm{CI}=2.73$ to 4.78 )

Table 1 shows the age distribution of the study population. The mean gestational age of the study population was $37.36 \pm 2.80$ weeks. There was no significant difference in the gestational age of the inborn $(37.25 \pm 3.16$ weeks) and out-born (37.62 \pm 1.66 weeks) babies. $(\mathrm{t}=-1.51, \mathrm{p}=0.13,95 \%$ C.I. $=-0.85$ to 0.11$)$

The mean age at presentation with jaundice was $3.43 \pm$ 3.76 days of life. Out-born babies tended to present at an older age ( $6.08 \pm 5.19$ days) than in-born babies $(2.47 \pm$ 2.48 days $)$. $(\mathrm{t}=-10.01, \quad \mathrm{p}=0.00,95 \%$ C.I. $=-4.32$ to 2.90). This was significant.

The mean maternal age of mothers was $30.44 \pm 5.63$ years. It was similar between mothers of the in-born babies (30.52 \pm 5.65 years) and of out-born babies $(30.26 \pm 5.62$ years $) .(t=0.50, p=0.62,95 \%$ C.I. $=-$ 0.77 to 1.29$)$.

\begin{tabular}{|c|c|c|c|c|c|}
\hline $\begin{array}{l}\text { Characteristics } \\
\text { Age }\end{array}$ & $\begin{array}{l}\text { Inborn } \\
\text { mean } \pm \text { SD }\end{array}$ & $\begin{array}{l}\text { Outborn } \\
\text { mean } \pm \text { SD }\end{array}$ & $\begin{array}{c}\text { Study } \\
\text { Population } \\
\text { mean } \pm \text { SD }\end{array}$ & t-test & p-value \\
\hline Presentation (days) & $2.47 \pm 2.48$ & $6.08 \pm 5.19$ & $3.43 \pm 3.76$ & -10.01 & 0.00 \\
\hline Maternal age (years) & $30.52 \pm 5.65$ & $30.26 \pm 5.62$ & $30.44 \pm 5.63$ & 0.50 & 0.62 \\
\hline Gestational age (weeks) & $37.25 \pm 3.16$ & $37.62 \pm 1.66$ & $37.36 \pm 2.80$ & -1.51 & 0.13 \\
\hline
\end{tabular}

\section{Anthropometric values}

Anthropometric values of in-born and referred babies are shown in table 2 . The birth weight of the study population ranged from $500 \mathrm{~g}$ to $4500 \mathrm{~g}$. The mean weight and occipito-frontal circumference of in-born babies was comparable to that of referred babies $(\mathrm{p}=0.86$ and 0.74 respectively). The length of referred babies $(51.85 \pm 5.06)$ was however significantly higher than that for in-born babies $(49.40 \pm 5.37, \mathrm{p}=0.00, \mathrm{t}=-5.03,95 \%$ C.I. $=$ 3.41to-1.49). 
Table 2: Anthropometric measurements of the study population

$\begin{array}{llll}\text { Characteristics } & \text { Inborn } & \text { Outborn } & \text { Study }\end{array}$

mean \pm SD

Population

t-test p-value

\begin{tabular}{lccccc}
\hline & & & & & \\
Birth weight $(\mathrm{gm})$ & $2,980 \pm 700$ & $2,990 \pm 510$ & $2,990 \pm 640$ & \multicolumn{1}{l}{-0.17} & \multicolumn{1}{l}{0.86} \\
Length $(\mathrm{cm})$ & $49.40 \pm 5.37$ & $51.85 \pm 5.06$ & $49.95 \pm 5.49$ & -5.03 & 0.00 \\
OFC $(\mathrm{cm})$ & $33.70 \pm 2.59$ & $33.88 \pm 8.38$ & $33.91 \pm 4.64$ & -0.33 & 0.74 \\
\hline
\end{tabular}

\section{Level of serum bilirubin}

Serum bilirubin of study subjects at admission ranged from 4 to $25 \mathrm{mg} / \mathrm{dL}$ with a mean of $9.95 \pm 4.59 \mathrm{mg} / \mathrm{dL}$. The mean SB value in out-born babies $(14.00 \pm 4.58$ $\mathrm{mg} / \mathrm{dL}$ ) was significantly higher than that observed amongst the in-born babies $(9.35 \pm 4.38 \mathrm{mg} / \mathrm{dL}: \mathrm{p}=$ $0.00)$ - Table 3.

The mean SB for the out-born babies who were discharged $(7.09 \pm 3.63 \mathrm{mg} / \mathrm{dL})$ was significantly higher than the mean SB of the in-born babies $(5.85 \pm 2.23 \mathrm{mg} / \mathrm{dL})(\mathrm{t}=$ $-5.22, \mathrm{p}=0.00,95 \%$ C.I. $=-1.78$ to -0.71 ).

\begin{tabular}{|c|c|c|c|c|}
\hline Characteristics & Inborn & Out-born & t-test & p-value \\
\hline Laboratory SB (mg/dl) & $9.35 \pm 4.38$ & $14.00 \pm 4.58$ & -11.19 & 0.00 \\
\hline $\begin{array}{l}\text { SB values at discharge } \\
(\mathrm{mg} / \mathrm{dl})\end{array}$ & $5.85 \pm 2.23$ & $7.09 \pm 3.63$ & -5.22 & 0.00 \\
\hline $\begin{array}{l}\text { SB values at DAMA } \\
(\mathrm{mg} / \mathrm{dl})\end{array}$ & $13.74 \pm 4.77$ & $14.80 \pm 1.67$ & -3.38 & 0.00 \\
\hline
\end{tabular}

\section{Clinical presentation of babies}

Common accompanying complaints were fever and poor suck in $253(53.6 \%)$ and $168(35.7 \%)$ of cases. Twenty seven $(5.7 \%)$ babies presented with lethargy and 24 $(5.1 \%)$ presented with jaundice and had no other complaints.

\section{Risk factors}

Seventy nine (16.7\%) mothers, all referred, admitted to storing the babies' clothes with naphthalene balls. Mentholatum was used for cord care in 189(40.0\%) of the study population while native herbs were used in 33 $(7.0 \%)$ cases. There was no identifiable risk factor in $171(36.3 \%)$ of subjects. The diagnoses of babies in this study were sepsis, prematurity, perinatal asphyxia and ABO incompatibility. The diagnosis of sepsis was made in $212(45.0 \%)$ babies. Other details with regard to diagnoses are as shown in table 4 .
Table 4: Diagnoses associated with neonatal jaundice in the study population
Diagnoses
$\mathrm{n}(\%)$

\begin{tabular}{lr}
\hline Sepsis & $212(45.0)$ \\
Prematurity & $94(19.9)$ \\
Asphyxia & $94(19.9)$ \\
ABO incompatibility & $36(7.6)$ \\
Multiple diagnoses & $36(7.6)$ \\
Total & $472(100)$ \\
\hline
\end{tabular}

\section{Treatment and outcome}

One hundred and sixty six (35\%) of the study population were treated with exchange blood transfusion. Phototherapy alone was the mode of treatment in $212(45 \%)$ patients while $94(20 \%)$ had no specific treatment directed at jaundice. Three hundred and seventy one (78.6\%) babies were discharged home: 41 (8.7\%) discharged against medical advice while $60(12.7 \%)$ died. Of the 60 mortality, 40 (21.5\%) were from the out-born section while $20(8.2 \%)$ were in-born babies. Thus, mortality was significantly higher among out-born babies than inborn babies. $\quad\left(\chi^{2}=14.61, p=0.00,95 \%\right.$ C.I. $=$ 0.17 to 0.60$)$ The mean gestational age $(23.00 \pm 0.10$ weeks) and birth weight $(500 \pm 100 \mathrm{~g})$ of babies that died in the in-born section was significantly lower than the mean gestational age $(37.00 \pm 1.16$ weeks $)$ and birth weight $(2,500 \pm 580 \mathrm{~g})$ of out-born subjects. $(\mathrm{p}=0.00$ in both cases). In the out-born section, the mean age of presentation of the babies that died was $8.00 \pm 4.62$ days and this was higher than the mean age of presentation of in-born subjects $(1.00 \pm 1.99$ day, $\mathrm{t}=-6.46, \mathrm{p}=0.00,95 \%$ C.I. $=-9.2$ to -4.8 .

Sepsis accounted for $70 \%$ (42/60) of deaths. Twelve deaths occurred in preterm babies while six deaths were associated with perinatal asphyxia. The mean SB $(16.15 \pm 0.75 \mathrm{mg} / \mathrm{dL})$ of babies that died in the out-born section was higher than the mean SB $(11.00 \pm 1.00 \mathrm{mg} /$ $\mathrm{dL})$ of babies that died in the inborn section. $(\mathrm{t}=-22.38$, $\mathrm{p}=0.00,95 \%$ C.I. $=-5.61$ to -4.77 ) 


\begin{tabular}{lclccc}
\hline \multicolumn{2}{l}{ Table 5: Characteristics of fatal cases. } \\
Characteristics & Inborn & Out-born & t-test & $\chi^{2}$ & p-value \\
\hline Case fatality n (\%) & $20(8.2)$ & $40(21.5)$ & - & 14.61 & 0.00 \\
Mean serum bilirubin (mg/dl) & $11.00 \pm 1.00$ & $16.15 \pm 0.75$ & -22.38 & - & 0.00 \\
Gestational age (weeks) & $23.00 \pm 0.10$ & $37.00 \pm 1.16$ & -53.65 & - & 0.00 \\
Age at presentation (days) & $1.00 \pm 1.99$ & $8.00 \pm 4.62$ & -6.46 & - & 0.00 \\
\hline
\end{tabular}

\section{Discussion}

Slightly more than a quarter of newborns in the current report presented with jaundice. The prevalence of jaundice in this study is lower than figures of $35 \%$ and $45.6 \%{ }^{11}$ previously reported from other centres in Nigeria. Sepsis and prematurity were major diagnosis identified in this study occurring in $45 \%$ and $20 \%$ of the study population. Other workers within and outside Nigeria have also observed neonatal jaundice in association with these two clinical entities. ${ }^{7,9,10,12}$

The case fatality rate herein reported is relatively high particularly in association with sepsis, prematurity and asphyxia. This is similar to the findings of Owa et al in Ile Ife Nigeria, in which septicaemia was associated with high mean SB level and the highest mortality. Sepsis is a cause of jaundice in the newborn period. Babies who have sepsis are likely to develop high levels of bilirubin from increased haemolysis and defective conjugation of bilirubin. ${ }^{2-3,6}$ Premature babies are prone to hyperbilirubinaemia because of immaturity of their liver enzymes resulting in defective conjugation of bilirubin and increased haemolysis from reduced red cell life span. ${ }^{1-3,6}$ Preterm babies are also prone to other clinical conditions like sepsis that may affect outcome in them. ${ }^{1-3}$

In $7.6 \%$ of the study population, $\mathrm{ABO}$ incompatibility was found to be the sole risk factor while multiple diagnoses were made in another $7.6 \%$ of the study population. $\mathrm{ABO}$ incompatibility is the most common form of haemolytic disease in the newborn period. This clinical entity is diagnosed in the presence of a positive direct coombs test, reticulocytosis and microspherocytes in a baby with haemolysis. ${ }^{1}$ However, only half of those with positive direct coombs test are likely to have significant haemolysis while some infants with negative direct coombs test have increased haemolysis. ${ }^{1,2}$ Hence, the development of hyperbilirubinaemia in babies with settings for $\mathrm{ABO}$ incompatibility depends on the conjugating ability of the babies. The use of naphthalene balls in storage of baby's clothes was found in $16.7 \%$ of the study population and only in mothers of out-born subjects. Naphthalene and mentholatum are recognized agents that cause haemolysis in G-6-PD deficient patients. ${ }^{13}$ Glucose-6-phosphate dehydrogenase enzyme deficiency is the most common red cell enzymopathy that causes neonatal haemolysis and jaundice. ${ }^{1-3}$ It is an $\mathrm{X}$ - linked recessive disorder that affects males; however, deficient females may also present with haemolysis and jaundice. Babies who are G-6-PD deficient are three times more prone to developing neonatal jaundice than G-6-PD deficient infants. ${ }^{2}$ The use of naphthalene balls in this study (16.7\%) is higher than what was found in Abakaliki ${ }^{7}$ where $6.9 \%$ of mothers of the out-born babies used naphthalene balls in storing their baby's clothes. Though the use of naphthalene balls was found in some babies in this study, the G-6-PD enzyme assay was not done for any of the babies in this study, as neonatal screening for the enzyme deficiency is not routinely carried out in our locale. None of the mothers of in-born neonates agreed to the use of naphthalene balls for storage of babies' clothes. Mothers of in-born neonates are more likely to attend antenatal care and may have been counseled on recognition of jaundice and avoidance of possible agents that can cause haemolysis in the newborn. This study found that significant proportions $(49 \%)$ of the mothers of the in-born babies were booked compared with mothers of the out-born babies $(13 \%)$. This finding was similar to what was found in Abakaliki. $^{7}$

The mean age of presentation with jaundice was three days. The out-born subjects presented significantly late (six days) than the in-born subjects (two days). The reason for early presentation of in-born babies may be that jaundice was recognized by the health workers before discharge from the hospital. Also, the mean serum bilirubin was higher in the out-born subjects than in inborn subjects possibly because the out-born subjects presented late compared with in-born subjects. These findings are similar to study from Abakaliki.

In this study, there was recourse to exchange blood transfusion in $35 \%$ of subjects and phototherapy in $45 \%$. The EBT rate in this study is higher than previously documented rate in Abakaliki and Ile-Ife, Nigeria.

Seventy eight percent of the study population was discharged home following treatment. Forty one $(8.7 \%)$ discharged against medical advice while $12.7 \%$ died. Mortality was higher amongst the out-born babies than amongst the in-born babies. This possibly is due to the fact that the out-born babies presented late and had higher serum bilirubin than the in-born babies.

\section{Conclusion}

The diagnoses identified in babies with jaundice in this study were sepsis, prematurity and $\mathrm{ABO}$ incompatibil- 
ity. Out-born newborns with jaundice presented to the hospitals late and had significantly higher serum bilirubin at presentation. Mortality was also higher in out-born babies than in-born babies. Early presentation of affected babies will significantly reduce mortality. Expectant mothers should also be encouraged to book their pregnancies and to deliver in standard health facilities. Adequate treatment of sepsis will significantly reduce mortality in these babies.

\section{Limitation of study}

This is a retrospective study; hence it was difficult to establish the contribution of other known risk factors like G-6-PD deficiency since routine screening of this enzyme deficiency is not done in the centre.
Conflict of interest : None

Funding : None

\section{References}

1. Stevenson DK, Madan A. Jaundice in the newborn. In: Rudolph CD, Rudolph AM, Hostetter MK, Lister G, Siegel NJ, editors. Rudolph's Paediatrics. $21^{\text {st }}$ ed.: McGraw Hill; 2003.

2. MacDonald MG, Seshia MMK, Mullet MD editors. Avery's neonatology. $6^{\text {th }}$ ed. Lippincott Williams and Wilkins; 2005.

3. Stoll BJ, Kliegman RM. Jaundice and hyperbilirubinaemia in the newborn. In: Behrman RE, Kliegman RM, Jenson HB, editors. Behrman Nelson textbook of paediatrics. $17^{\text {th }}$ ed. Philadelphia: WB Saunders; 2004.

4. Band J. Newborn Jaundice. Available at:http://www.dukehealth.org/ health_library ad-

vice_from_doctors/ your_childs_health/? b_start:int $=70$. Accessed on $18^{\text {th }}$ November, 2011
5. Ibe BC. Neonatal jaundice. In: Azubuike JC, Nkanginieme KEO, editors. Paediatrics and Child Health in a tropical region. $2^{\text {nd }}$ ed. University of Port Harcourt press; 2007.

6. Kaplan M, Hammerman C. Bilirubin and the genome: the hereditary basis of unconjugated hyperbilirubinaemia. Pharmacogenomics. 2005; 3: 21-42.

7. Onyearugha $\mathrm{CN}$, Onyire BN, Ugboma HAA. Neonatal jaundice: prevalence and associated factors as seen in Federal Medical Center, Abakaliki, Southeast Nigeria. J. Clin. Med. Res. 2011; 3(3): 4045.

8. Guidelines for detection, management and prevention of hyperbilirubinaemia in term and late preterm newborn infants (35 or more weeks of gestation). Fetus and Newborn Committee, Canadian Paediatric Society. Paediatr Child Hlth. 2007; 12(Suppl B): $1 B$ $-12 B$.
9. Korejo HB, Bhurgri GR, Bhand S, Qureshi MA, Dahri GM, Chotian RK. Risk factors for kernicterus in neonatal jaundice. Gomal J Med Sci. 2010; 8(1): 12-15.

10. Owa JA, Dawodu AH. Neonatal jaundice among Nigerian preterm infants. West Afr J Med. 1990; 9 (4): 252-257.

11. Owa JA, Osinaike AI. Neonatal morbidity and mortality in Nigeria. Indian J Pediatr. 1998; 65(3): 441 -449 .

12. Ahmed H, Yakubu AM, Hendrickse RG. Neonatal jaundice in Zaria, Nigeria. West Afr. J Med. 1995; 14(1): 15-23.

13. Valaes T, Doxiadis SA, Fessas P. Acute haemolysis due to naphthalene inhalation. J Paediatr. 1963; 63: 904-915. 